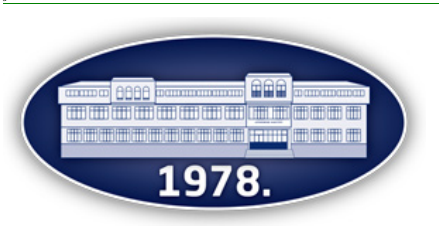

Publisher: Faculty of Agronomy Čačak

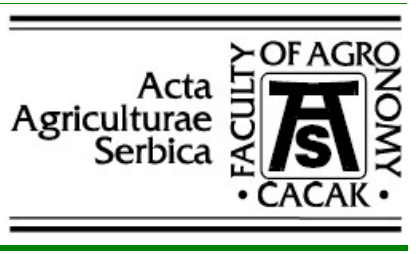

\title{
Stabilized sewage sludge - sanitary aspects and potential for conversion to biosolids
}

\author{
Jelena Jovičić-Petrović *, Anđelka Mijačić, Blažo Lalević, Igor Kljujev, Vera Karličić, \\ Vera Raičević
}

Faculty of Agriculture, University of Belgrade, Nemanjina 6, 11080 Zemun

*Corresponding author: jelenap@agrif.bg.ac.rs

Received 16 April 2021; Accepted 20 September 2021

\begin{abstract}
A B S T R A C T
The improvement of wastewater treatment techniques is of crucial importance for effluent quality, but it also results in an increased amount of waste sludge. Dehydrated sludge contains organic matter and nutrients, and therefore it can be used in agriculture and bioremediation, but it is considered a potential source of environmental pollution. As the sludge analyzed in the research does not contain impermissible levels of organic and inorganic pollutants, the aim of the research was to examine microbiological, particularly sanitary, aspects and potential for its further use. Microbial diversity was determined by the standard serial dilution technique and selective media, and sanitary quality indicators (total coliforms, fecal coliforms, Escherichia coli and Salmonella spp.) were determined by the MPN method. The abundance of fungi, actinomycetes, and bacteria (ammonifiers, spore-forming bacteria and Pseudomonas spp.) indicate possibilities for further use of the sludge. The chemical analysis included the following parameters: total nitrogen $(\mathrm{N})$, phosphorus in the form of $\mathrm{P}_{2} \mathrm{O}_{5}$ (available $\mathrm{P}$ ), organic carbon (C), $\mathrm{C} / \mathrm{N}$ ratio, $\mathrm{pH}$, and water content. The chemical composition indicates the potential of sewage sludge to be used as a soil fertilizer, but its $\mathrm{C} / \mathrm{N}$ ratio is not adequate to enable successful conversion to biosolids by the composting process. The obtained results indicate a significant level of microbiological contamination, which was most pronounced in the centre of the stabilized sludge pile. The research showed the necessity to conduct further studies on the microbial diversity and sanitary aspects of sewage sludge for proper waste sludge management.
\end{abstract}

Keywords: biosolids, Escherichia coli, microbial diversity, sanitary quality, sewage sludge.

\begin{abstract}
И 3 В О Д
Унапређење техника третмана отпадних вода од кључног је значаја за квалитет ефлуента, али такође резултира повећаним количинама отпадног муља. Дехидрисани муљ садржи органску материју и нутријенте, тако да може бити искоришћен у пољопривреди и биоремедијацији, али се сматра и потенцијалним извором загађења животне средине. Муљ анализиран у овом раду не садржи недозвољене количине органских и неорганских загађивача, тако да је циљ истраживања био да се истраже микробиолошки, нарочито санитарни аспекти и потенцијал за примену муља. Микробиолошки диверзитет је одређен стандардном методом разређења и применом селективних подлога, а индикатори санитарног квалитета (укупне и фекалне колиформне бактерије, Escherichia coli и Salmonella spp.) одређене су МПН методом. Бројност гљива, актиномицета и бактерија (амонификатора, спорогених бактерија и Pseudomonas spp.) указује на могућности за даљу примену муља. Хемијска анализа обухватила је следеће параметре: укупан азот (N), фосфор у облику $\mathrm{P}_{2} \mathrm{O}_{5}$ (приступачан P), органску форму угљеника (C), C/N однос, рН и садржај влаге. Хемијски састав указује на потенцијал за примену муља као фертилизатора, али C/N однос није адекватан како би се обезбедила конверзија у биосолид у процесу компостирања. Добијени резултати указују на значајан ниво микробиолошке контаминације, која је најизраженија у центру гомиле стабилизованог муља. Истраживања указују на неопходност даљег испитивања микробног диверзитета и санитарних аспеката муља из постројења за третман отпадних вода са циљем адекватног управљања отпадом.
\end{abstract}

Кључне речи: биосолид, Escherichia coli, микробиолошки диверзитет, санитарни квалитет, отпадни муљ.

\section{Introduction}

Effective and environmentally friendly wastewater treatment processes are being applied worldwide. Wastewater treatments result in a considerable amount of sewage sludge, and there is an urgent need to develop strategies to increase its reuse. Sludge management encompasses different procedures starting from disposal all the way to obtaining different valuable products, and therefore sludge is a valuable by-product or waste material, depending on the implemented technology. Common practices for the management of sewage sludge include its use as a soil amendment or final disposal (Grobelak et al., 2019). Efforts in sludge treatment are being directed towards: volume reduction, stabilization, energy and nutrient recovery, and beneficial use of final products (Tezel et al., 2011). 
The quantity of sewage sludge produced in the EU is estimated at more than 10 million tons (dry solids) each year, but the percentage of sludge being recycled and used in agriculture varies across countries (Grobelak and Jaskulak, 2019). Serbia has accepted the Urban Waste Water Treatment Directive (UWWTD $91 / 271 / \mathrm{EEC}$ ) and the obligation to solve this problem, practically from the very beginning. Only $12 \%$ of wastewater being discharged to the sewage network (which receives $58 \%$ of total municipal wastewater) is being subjected to a purification process (Marko et al., 2020). Consequently, sludge treatment considerations have not received sufficient attention yet.

Sludge separated after wastewater treatment can pose a significant environmental risk due to the potential presence of heavy metals and pathogenic microorganisms, and a high water and organic matter content (Bian et al., 2018). The dry matter of activated sludge consists of $70-90 \%$ organic and $10-30 \%$ inorganic compounds (Vujović et al., 2016). The high content of organic matter and nutrients (mainly nitrogen and phosphorus) in sewage sludge has indicated its potential application in agriculture or soil bioremediation (Rorat et al., 2019). Despite the significant amount of nutrients, the chemical and microbiological properties of unprocessed sludge are limiting its application, which emphasizes the necessity of further treatment before use or disposal. Aerobic stabilization is a common method because of the high water and organic matter content. After aerobic stabilization and pressing, waste sludge still contains a significant amount of water, $70-75 \%$ (Bianchini et al., 2015), which makes it unstable and increases transport costs (Kosowski et al., 2020). The composition of stabilized sludge is difficult to define because wastewater properties are variable and, additionally, sludge is a mixture from different phases of wastewater treatment. As a result, there is a need for comprehensive ecotoxicological, sanitary and environmental considerations before sludge enters the circular economy and is converted to a safe fertilizer.

Sewage sludge makes a perfect environment for different microorganisms, and it is characterized by great biodiversity, which can vary depending on sewage origin, treatment, industrial activity, and other factors (Nascumento et al., 2018). While microflora has the potential for further sludge treatment, harmful microorganisms need to be controlled before sludge application. The most significant pathogens related to sludge are Salmonella representatives, with Salmonella tiphy as the most severe, but other enteric bacteria such as E. coli are also commonly detected (Romdhana et al., 2009). According to the EPA waste classification (EPA, 2018), sewage sludge belongs to the group of harmless biodegradable waste (index number 1908 05).

The levels of total hydrocarbons, polychlorinated biphenyls, polycyclic aromatic hydrocarbons, and heavy metals in the studied sludge are below legislative limits (unpublished data from the facility). Those data indicate possibilities for sludge application after the composting process. The aim of this study was to characterize stabilized sludge from the wastewater treatment facility in Šabac (Serbia) and estimate the effect of stabilization on sludge microbiological and chemical characteristics, with particular emphasis on the sanitary aspect.

\section{Materials and methods}

\subsection{Sewage sludge}

The waste material used in the study was sampled in the wastewater treatment facility in Šabac. About 6 million $\mathrm{m}^{3}$ of wastewater are treated each year, and the treatment results in 20-25 t of waste sludge each day. Wastewater treatment in the facility includes primary and secondary treatment. The remaining sludge from the two phases is mixed at a ratio of $1: 2-1: 3$. The mixture is subjected to aerobic stabilization, after which the sludge is pressed and disposed of in the facility surroundings. Two kinds of samples were taken: fresh sludge and sludge subjected to stabilization. For both of them, two layers were sampled: the surface layer and the middle of the pile. Representative samples were stored at $4^{\circ} \mathrm{C}$ before analyses.

\subsection{Chemical characterization}

The chemical characterization of sewage sludge included the following parameters: water content $(\mathrm{w})$, total nitrogen content $(\mathrm{N})$, phosphorus in the form of $\mathrm{P}_{2} \mathrm{O}_{5}$, total carbon content (C), carbon:nitrogen ratio (C:N), and $\mathrm{pH}$. Water content was determined by drying at $105^{\circ} \mathrm{C}$ until constant weight, the Kjeldahl method was used for total $\mathrm{N}$ determination (Bremner, 1996), $\mathrm{pH}$ was measured electrochemically (Eutech $\mathrm{pH} 700$, Eutech Instruments Pte Ltd.). Total $\mathrm{P}_{2} \mathrm{O}_{5}$ was determined spectrophotometrically (UV/VIS 1166, Labomed Inc., USA) after acid digestion (AOAC International, 2005), and total $\mathrm{C}$ by the dichromate method described by Tjurin and modified by Van Ranst (1999).

\subsection{Microbiological characterization}

The microbiological characterization of sewage sludge was performed by the standard serial dilution technique combined with selective nutrient media. Fungi were determined on Rose Bengal medium with streptomycin (Peper et al., 1995), total ammonifiers were detected on Nutrient agar (Torlak, Serbia), and Pseudomonas spp. on Citrimide agar (Merck, Germany). Actinomycetes were enumerated on starch ammonia agar consisting of: starch, $10 \mathrm{~g} ;\left(\mathrm{NH}_{4}\right)_{2} \mathrm{SO}_{4}, 1 \mathrm{~g}$; $\mathrm{MgSO}_{4} \times 7 \mathrm{H}_{2} \mathrm{O}, 1 \mathrm{~g} ; \mathrm{NaCl}, 1 \mathrm{~g} ; \mathrm{KNO}_{3}, 1 \mathrm{~g}, \mathrm{CaCO}_{3}, 3 \mathrm{~g}$; agar $20 \mathrm{~g}$, and $1 \mathrm{~L}$ of distilled water. The numbers of sporogenic bacteria were determined on Nutrient agar (Torlak, Serbia) amended with the sample dilution subjected to pasteurization at $80^{\circ} \mathrm{C}$ for $10 \mathrm{~min}$. Analyses were performed in three replications.

\subsection{Sanitary quality}

The MPN method was used for the determination of Salmonella spp., total and fecal coliform bacteria, and E. coli. For the determination of total, fecal coliform bacteria, and E. coli, McConkey broth (Torlak, Serbia) was used for the first test, and Endo agar (TM media, India) for confirmation test, while Selenite Broth (Torlak) and SS agar (Torlak, Serbia) were used for Salmonella determination in the samples. The incubation lasted $48 \mathrm{~h}$ at $37^{\circ} \mathrm{C}$, except for fecal coliform bacteria, which were determined after incubation at 
$44^{\circ} \mathrm{C}$. MPN tests were performed in three replications per dilution.

\section{Results and discussions}

The reuse of sludge originating from wastewater treatment plants in agriculture, forestry, and horticulture is based on its high content of nutrients (Vouk et al., 2011). Organic matter improvement,

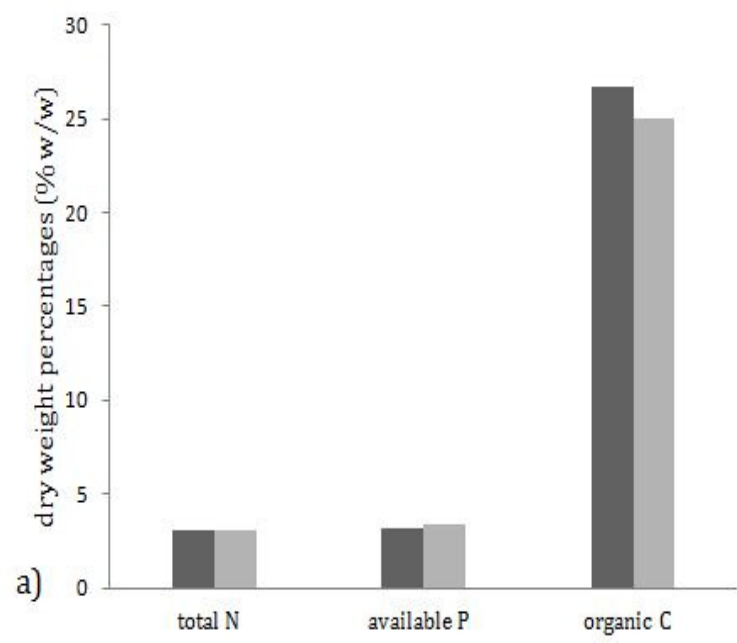

stimulation of microbiological processes, beneficial soil conditioning properties, and an increase in plant macronutrient availability are the main benefits of sludge use as a biofertilizer (Singh and Agrawal, 2008). At the same time, some negative aspects are also observed, such as an increase in toxic elements and pathogenic microorganisms in the soil (Kulling et al., 2001).

Figure 1. Chemical characteristics of fresh (a), and stabilized (b) sludge from wastewater treatment: total nitrogen $(\mathrm{N})$, available phosphorus in the form of $\mathrm{P}_{2} \mathrm{O}_{5}$ (available P), and organic carbon (C); $\square$ surface layer, $\square$ center.

The samples of sludge from the wastewater facility in Šabac contained significant amounts of $\mathrm{N}$ and $\mathrm{P}$ (Figure 1), which makes it a good substrate supplement for plant growth. The amounts of these nutrients are within the usual range of concentrations for such waste material, i.e. $2-6 \%$ for $\mathrm{N}$, and $1-7 \%$ for $\mathrm{P}$ (NakomčićSmaragdakis et al., 2012). Also, some differences between surface and central layers of the sludge pile were observed, as well as between fresh and stabilized sludge. Stabilized sludge may have a lower content of organic $\mathrm{C}$, since one part of it could be lost during the stabilization process (Yoshida et al., 2015), which was confirmed by our results. The decrease in total $\mathrm{C}$ was more pronounced in the central parts of sludge due to increased microbial activity correlated with the water content. The loss of total $\mathrm{N}$ is also expected during stabilization processes; in the central part and surface layer, total $\mathrm{N}$ content decreased by $21.5 \%$ and $23.2 \%$, respectively. Nitrogen loss occurred through the evaporation of ammonia (Smith and Durgam, 2000), and was slightly more pronounced in the surface layers. The amount of available $\mathrm{P}$ in surface layers remained unchanged after the stabilization process, but it increased by $4.8 \%$ in the central part, probably as a result of microbial activity and aerobic decomposition of organic compounds.

Table 1.

Carbon/nitrogen ratio $(\mathrm{C} / \mathrm{N}), \mathrm{pH}$ and dry weight percentage $(\% \mathrm{dw})$ of residue sludge from wastewater treatment

\begin{tabular}{cccc}
\hline Sample & \multicolumn{3}{c}{ Parameter } \\
\cline { 2 - 4 } & $\mathrm{C} / \mathrm{N}$ & $\mathrm{pH}$ & $\% \mathrm{dw}$ \\
\hline Stabilized sludge, surface & $8.6: 1$ & 7.59 & 80.79 \\
Stabilized sludge, center & $8.2: 1$ & 8.31 & 17.34 \\
Fresh sludge, surface & $7.4: 1$ & 7.63 & 22.71 \\
Fresh sludge, center & $8.0: 1$ & 8.17 & 19.07 \\
\hline
\end{tabular}

Water content in the surface layer of stabilized sludge pile was significantly lower (Tab.1), as the result of longer sludge disposal and dry surface crust formation. The $\mathrm{pH}$ of surface layers was lower than that of the central parts, possibly due to a higher abundance of fungi on the surface (Table 2) and their metabolic activity.

The low $\mathrm{C} / \mathrm{N}$ ratio in sludge samples (Table 1) indicates unfavorable conditions for successful composting. The usual recommendation for the $\mathrm{C} / \mathrm{N}$ setting is co-composting with some other types of waste containing a high $\mathrm{C} / \mathrm{N}$ ratio, such as lignocellulose waste from primary agriculture, mushroom production, horticultural waste, sawdust, or other types (Kulikowska, 2016). Previous studies indicate that co-composting with wastes containing a high organic $\mathrm{C}$ content can have a positive effect on the composting process and ammonia assimilation by nitrifiers, and can lead to an increase in composting temperature, an increase in humic matter content, and a decrease in pathogenic bacteria abundance (El Kadiri Boutchich et al., 2015; Kulikowska, 2016; Li et al., 2013; Meng et al., 2018). Mixing with lignocellulose waste results in a decrease in the total number of pathogenic 
microorganisms in the initial material of the composting pile. At the same time, $\mathrm{C} / \mathrm{N}$ adjustment will lead to better conditions to achieve higher temperatures, which improve the sanitation of the composting mass (El Kadiri Boutchich et al., 2015).

Table 2.

Microbiological community in sewage sludge (numbers of specific groups of microorganisms as CFU g-1 $\mathrm{dw}^{\text {) }}$

\begin{tabular}{|c|c|c|c|c|c|}
\hline \multirow[b]{2}{*}{ Sample } & \multicolumn{5}{|c|}{ Abundance of microbial groups (CFU/g dw) } \\
\hline & 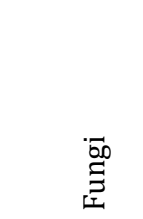 & 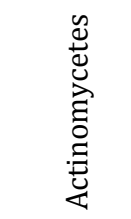 & 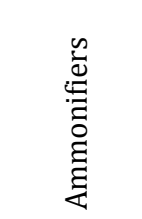 & 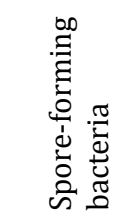 & 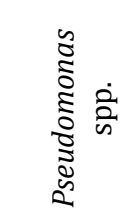 \\
\hline Stabilized sludge, surface & $7.34 \times 10^{7}$ & $8.58 \times 10^{4}$ & $1.82 \times 10^{10}$ & $9.28 \times 10^{6}$ & $1.41 \times 10^{4}$ \\
\hline Stabilized sludge, center & $3.46 \times 10^{6}$ & $3.34 \times 10^{5}$ & $1.91 \times 10^{8}$ & $4.99 \times 10^{5}$ & $1.65 \times 10^{4}$ \\
\hline Fresh sludge, surface & $7.93 \times 10^{4}$ & $6.43 \times 10^{5}$ & $2.28 \times 10^{10}$ & $1.38 \times 10^{6}$ & $1.68 \times 10^{5}$ \\
\hline Fresh sludge, center & $7.34 \times 10^{4}$ & $2.09 \times 10^{5}$ & $1.90 \times 10^{10}$ & $2.10 \times 10^{5}$ & $4.19 \times 10^{3}$ \\
\hline
\end{tabular}

The abundance of fungi was significantly higher in stabilized sludge than in fresh sludge. The difference between the surface and the inner layer was present in both types of sludge, but it was more pronounced in stabilized sludge (Table 2). Water reduction in the surface layer during sludge stabilization favored fungi over the other microbes. The macromorphological observations of fungal colonies on selective medium indicated that the representatives of Mucor spp. were the most dominant fungal population. The presence of Trichoderma spp. was recorded occasionally. It is known that some Mucor representatives are able to adapt to changes in $\mathrm{pH}$ and oxygen content (Reunwai et al., 2010). Mucor and Trichoderma representatives are known as bioremediation agents, and therefore their activity can be involved in the removal of toxic compounds (Khatoon et al., 2021).

A very high prevalence of ammonifiers was noted in analyzed samples (Table 2). This was expected, considering the high organic matter content of the sludge, and its tendency to be unstable and easily decomposed. This part of microbiota plays an important role in the composting process. Aerobic conditions in the surface layer increased the presence of spore-forming bacteria, which made up a significant portion of the ammonifier group. Spore-forming ammonifiers belonging to Bacillus genus are the main bacterial component in organic carbon degrading microflora, especially in the thermophilic phase of the composting process (He et al., 2013).

Table 3.

Sanitary quality of sewage sludge MPN/10g dw
Actinomycete representatives were abundant in samples (Table 2), as the result of their affinity to alkaline conditions (Table 1). Those microorganisms play an important role in organic matter decomposition and can be an important factor in the composting process. Moreover, their antagonistic activity towards harmful microorganisms such as human pathogens (Abdin et al., 2016) can lead to improved compost quality.

Pseudomonas spp. were significantly abundant, especially in the surface layer of the fresh sludge (Table 2 ). This genus covers not only human, animal, and plant pathogens, but also beneficial plant growth promoters, biocontrol agents, and microbes capable of degrading a wide spectrum of xenobiotics (Palleroni et al., 2010).

Meerbergen et al. (2017) reported that Proteobacteria, Bacteroidetes, and Actinobacteria are predominant in domestic sludges, and Nascumento et al. (2018) results confirm the predominance of Proteobacteria, followed by Bacteroidetes and Firmicutes. Bearing in mind that each sludge originates from different wastewater sources and that industrial wastewater sludge can be characterized by lower diversity compared to domestic sludge (Nascumento et al., 2018), treatment planning for sludge bioconversion should involve the analysis of the microbial diversity of the specific sludge. Further research should incorporate culture-independent techniques, aimed towards a deeper understanding of sludge microbiota.

\begin{tabular}{ccccc}
\hline Sample & Total coliforms & Fecal coliforms & Escherichia coli & Salmonella spp. \\
\hline Stabilized sludge, surface & $>13.580$ & $>13.580$ & 247 & 247 \\
\hline Stabilized sludge, center & $>64.706$ & $>64.706$ & 212 & 64.706 \\
\hline Fresh sludge, surface & $>50.000$ & $>50.000$ & $>50.000$ & 414 \\
\hline Fresh sludge, center & $>57.895$ & $>57.895$ & $>57.895$ & 8421 \\
\hline
\end{tabular}

The surface layer of stabilized sludge was characterized by the lowest level of all examined microbial quality indicators (Tab. 3). The other samples contained more than $50000 \mathrm{MPN} / 10 \mathrm{~g}$ of total and fecal coliform bacteria, as well as of $E$. coli in the surface and center of fresh sludge. The center of stabilized sludge had a specifically pronounced abundance of Salmonella spp., which are among the most important microbial contaminants of sludge (Romdhana et al., 2009). According to the current legislative regulations in the Republic of Serbia, the limit for Salmonella spp. in compost used in agriculture is $10 \mathrm{MPN} / 10 \mathrm{~g} \mathrm{dw}$ (Official Gazette RS, No. 67/2011, 48/2012, and 1/2016). According to the USA legislation (US EPA, 1993), 
composts originating from biosolids can be classified as A class (without detected pathogens) and B class (with certain levels of pathogenic microorganisms), but the standard sets restrictions on their use in agriculture. The restrictions are related to crop rotation and restricted periods for use of agricultural products after compost application. E. coli was also a common contaminant of both fresh and stabilized sludge (Wéry et al., 2008).

The presence of pathogenic bacteria in sludge can put food production at risk if sludge is used on fields. $E$. coli and Salmonella spp. are capable of surviving and multiplying inside compost particles for up to a few months after compost application (Eamens et al., 2006). Given their propagation potential in soil and risk for human health, their populations in waste materials should be of particular interest. The results indicate that sludge should be further treated before use and that these treatments should include sanitation. One solution could be to use composting as a strategy for stabilized sludge treatment. The proper maintenance of elevated temperature during composting leads to a significant improvement in microbiological quality (Epstein, 2002; Đokić et al., 2014).

\section{Conclusions}

The stabilization of sewage sludge results in moderate changes in its water content and chemical and microbiological characteristics. Further treatments are needed to enable sludge involvement in the circular economy. Composting of stabilized sewage sludge is a cost-effective process that has many benefits such as reducing the total volume of waste, enhancing soil fertility, improving sludge structure and water holding capacity, reducing the abundance of pathogenic bacteria and xenobiotics, recycling other lignocellulose waste at the same time. Variability in biological communities and their diversity indicate the need for further research focused on the sanitary characterization of sewage sludge.

\section{Acknowledgment}

This experiment was conducted with the support of the Ministry of Education, Science and Technological Development of the Republic of Serbia (Grant No. 45103-9/2021-14/ 200116).

\section{Declaration of competing interest}

The authors have no conflict of interest to declare.

\section{References}

Abidin, Z.A.Z., Malek, N.A., Zainuddin, Z., Chowdhury, A.J.K. (2016) Selective isolation and antagonistic activity of actinomycetes from mangrove forest of Pahang, Malaysia. Frontiers in Life Science, 9(1), 24-31.

AOAC International (2005). Official methods of analysis of AOAC International. 18th Edition. AOAC International, Gaithersburg, MD. AOAC 978.01.

Bian, Y., Yuan, Q., Zhu, G., Ren, B., Hursthouse, A., Zhang, P. (2018). Recycling of Waste Sludge: Preparation and Application of Sludge-Based Activated Carbon. International Journal of Polimer Science, Article ID 8320609, 17 pages.

Bianchini, A., Bonfiglioli, L., Pellegrini, M., Saccani, C. (2015). Sewage sludge drying process integration with a waste-to-energy power plant. Waste management, 42, 159-165.

Bremner, J.M. (1996). Nitrogen-total. In: Sparks, D.L. (Ed.), Methods of Soil Analysis, Part 3- Chemical Methods, SSSA book series 5, Soil Science Society of America, Medison, Wisconsin, USA, pp, 1085-1121.

Council of European Union (1991). Urban Waste Water Treatment Directive (UWWTD 91/271/EEC) concerning urban waste-water treatment. OJ L 135, 30.5.1991, pp. 40-52.

Đokić, D., Lugić, Z., Terzić, D., Jevtić, G., Milenkovic J. (2014). Processing biodegradable waste by applying aerobic digester EWA. Acta Agriculturae Serbica, 19(38), 133-142.

El Kadiri Boutchich, G. , Tahiri, S., Mahi, M., Gallart-Mateu, D., de la Guardia, M., Aaefane, A., Lhadi, E.K., El Krati, M. (2015). Characterization of activated sludge from domestic sewage treatment plants and their management using composting and co-composting in aerobic silos. Journal of Materials and Environmental Science, 6(8), 2206-2220.

Environmental Protection Agency, EPA (2018). Waste Classification List of Waste \& Determining if Waste is Hazardous or Non-hazardous. Environmental Protecion Agency, Ireland. pp. 7-33.

Epstein, E. (2002). Land application of sewage sludge and biosolids. 1st Edition. CRC Press. Boca Raton, 216 p.

Fatunla, K., Inam, E., Essien, J., Dan, E., Odon, A., Kang, S., Semple, K.T. (2017). Influence of composting and thermal processing on the survival of microbial pathogens and nutritional status of Nigeria sewage sludge. International Journal of Recycling of Organic Waste in Agriculture, 6(4), 301-310.

Grobelak, A., Czerwińska, K, Murtaś, A. (2019). General considerations on sludge disposal, industrial and municipal sludge. In: Prasad, M.N.V., de Campos Favas, P.J., Vithanage, M., Mohan, S.V. (Eds.), Industrial and Municipal Sludge, ButterworthHeinemann, pp. 135-153.

Grobelak, A., Jaskulak, M. (2019). Sludge multifunctions in a phytobiome - Forest and plantation application including microbial aspects. In: Prasad, M.N.V., de Campos Favas, P.J., Vithanage, M., Mohan, S.V. (Eds.), Industrial and Municipal Sludge, ButterworthHeinemann, pp. 323-336.

He, Y., Xie, K., Xu, P., Huang, X., Gu, W., Zhang, F., Tang, S. (2013). Evolution of microbial community diversity and enzymatic activity during composting. Research in Microbiology, 164(2), 189-198.

Khatoon, K., Rai, J.P.N., Jillani, A. (2021). Role of fungi in bioremediation of contaminated soil. In: Sharma, V.K., Shah, M.P., Parmar, S., Kumar, A. (Eds.), Fungi bio-prospects in sustainable agriculture, environment and nano-technology, Academic Press, pp. 121-156.

Kosowski, P., Szostek M. , Pieniazek , R., Antos, P., Skrobacz, K, Piechowiak, T., Zaczek, A., Józefczyk, R., Balawejder, M. (2020). New Approach for Sewage Sludge Stabilization with Ozone. Sustainability, 12(3), 886.

Kulikowska, D. (2016). Kinetics of organic matter removal and humification progress during sewage sludge composting. Waste management, 49, 1962013.

Kulling, D., Stadelmann, F., Herter, U. (2001). Sewage Sludge - Fertilizer or Waste? UKWIR Conference, Brussels.

Li, Y., Li, W., Wu., C., Wang., K. (2013). New insights into the interactions between carbon dioxide and ammonia emissions during sewage sludge composting. Bioresource Technology, 136, 385-393.

Marko, I., Csicsaiova, R., Stanko, S., Skultetyova, I., Hrudka, J. (2020). Analysis of the recent state of sewage network in Serbia. IOP Conference Series: Earth and Environmental Science, 444, 012038.

Meerbergen, K., Van Geel, M., Waud, M., Willems, K. A., Dewil, R., Van Impe, J., Appels, L., Lievens, B. (2017). Assessing the composition of microbial communities 
in textile wastewater treatment plants in comparison with municipal wastewater treatment plants. Microbiology Open, 6(1), e00413.

Meng, L., Zhang, S., Gong, H., Zhang, X., Wu, C., Li, W. (2018). Improving sewage sludge composting by addition of spent mushroom substrate and sucrose. Bioresource Technology, 253, 197-203.

Nakomčić-Smaragdakis, B., Stupavski, M., Čepić, Z., Momčilović, D. (2012). Municipal wastewater treatment and biogas production. Savremena poljoprivredna tehnika, 38(2), 131-143.

Nascimento, A.L., Souza, A.J., Andrade, P.A.M., Andreote, F.D., Coscione, A.R., Oliveira, F.C., Regitano, J.B. (2018). Sewage sludge microbial structures and relations to their sources, treatments, and chemical attributes. Frontiers in Microbiology. 9, 1462.

Palleroni, N.J., Pieper, D.H., Moore, E.R.B. (2010). Microbiology of hydrocarbon-degrading Pseudomonas. In: Timmis, K.N. (Ed.), Handbook of hydrocarbon and lipid microbiology, Springer, Berlin, Heidelberg, pp. 1787-1798.

Peper, I.L., Gerba, C.P., Brendencke, J.W. (1995). Environmental Microbiology, Academic Press, San Diego, pp. 11-33.

Romdhana, M.H., Lecomte, D., Ladevie, B., Sablayrolles, C. (2009). Monitoring of pathogenic microorganisms contamination during heat drying process of sewage sludge. Process Safety and Environmental Protection, 87(6), 377-386.

Rorat, A., Courtois, P., Vandenbulcke, F., Lemiere, S. (2019). Sanitary and environmental aspects of sewage sludge management. In: Prasad, M.N.V., de Campos Favas, P.J., Vithanage, M., Mohan, S.V. (Eds.), Industrial and Municipal Sludge, ButterworthHeinemann, pp. 155-180.
Singh, R.P., Agrawal, M. (2008). Potential benefits and risks of land application of sewage sludge. Waste Management, 28, 347-358.

Smith, S.R., Durham, E. (2000). Nitrogen release and fertilizer value of thermally dried biosolids. Water and Environment Journal, 16(2), 121-126.

Tezel, U., Tandukar, M., Pavlostathis, S.G. (2011) Anaerobic biotreatment of municipal sewage sludge. In: Moo-Young, M. (Ed.), Comprehensive Biotechnology, second Edition, Academic Press, Massachusetts, pp. 447-461.

US EPA (U.S. Environmental Protection Agency) (1993). The standards for use or disposal of sewage sludge. Final rules. Federal register, Washington, DC. EPA 822/Z-93-001.

Van Ranst, E., Verlo, M., Demeyer, A., Pauwels, J.M. (1999). Manual for the soil chemistry and fertility laboratory. Analytical methods for soil and plants, equipment and management of consumables. University of Gent, Gent, Belgium, 243 p.

Vouk, D., Malus, D., Tedeschi, S. (2011). Muljevi s komunalnih uređaja za pročišćavanje otpadnih voda. Građevnar, 63(4), 341-349.

Vujovic, B., Teodorovic, S., Lalevic, B., Raicevic, V. (2016). Praktikum: Tehnologija otpadnih voda. Univerzitet u Beogradu, Poljoprivredni fakultet, Beograd, $208 \mathrm{p}$.

Wéry, N., Lhoutellier, C., Ducray, F., Delgenèse, J.F., Godon, J.J. (2008). Behavior of pathogenic and indicator bacteria during urban wastewater treatment and sludge composting, as revealed by quantitative PCR. Water Research, 42(1-2), 53-62.

Yoshida, H., Nielsen, M.P., Scheutz, C., Jensen, L.S., Christensen, T.H., Nielsen, S., Bruun, S. (2015). Effects of sewage sludge stabilization on fertilizer value and greenhouse gas emissions after soil application. Acta Agriculturae Scandinavica, Section $B$ - Soil \& Plant Science, 65(6), 506-516. 